\title{
Professor Sir Gareth Roberts FRS - A Tribute (1940-2007)
}

Gareth Gwyn Roberts was a very distinguished physicist, industrial scientist and University Administrator, with a passionate commitment to policies that would encourage the growth of science and engineering. His skill and charismatic leadership were well recognized by the government of the UK where he held high positions that enabled him to have a positive

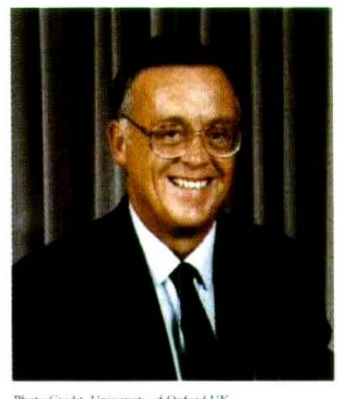
impact in many areas related to the development of Science, Science Education, Technology diffusion as well as Popularization of Science.

The writer first met him in 1997 when he led a team from the University of Sheffield, UK to Sri Lanka for a special Convocation for the conferment of a degree of Doctor of Science Honoris Causa. On this occasion he delivered several popular lectures, including one to the members of the SLAAS.

Sir Gareth also met and had valuable discussions with our first Minister of Science and Technology, the late Mr. Bernard Soysa. "What an extraordinary man", Mr Soysa was to observe.

Sir Gareth was a simple man who immediately showed interest in a tie up with the University of Sri Lanka and the University of Sheffield for a joint effort in Medical Education. Unfortunately for reasons not clear, this did not materialize, and what could have been a massive gain for Sri Lanka ended up in the University of Malaysia.

Sir Gareth was then the distinguished Vice Chancellor of the University of Sheffield and the Chairman of the Committee of Vice Chancellors and Principals of the United Kingdom.

Sir Gareth was a Welshman, and brought up in a Welsh speaking home. He was to master English at school, and progressed to the University College of North Wales in Bangor, where he obtained a first class in Physics and a $\mathrm{PhD}$ in semi-conductor Physics.
He had a meteoric rise in the academic world and by the age of 35 was a Professor of Physics at the New University of Ulster. He then moved to Durham where he was Head of the Department of Applied Physics \& Electronics. He was equally at ease at the interface of Physics and Engineering. He worked with the Xerox Corporation in Rochester NY, and then at ICI where he developed their capability in Electronics. In 1985 he took up the challenging task of Director of Research at Thom-EMI This gave him the opportunity of working in the Industrial as well as Academic domains, and he functioned at the same time as the Visiting Professor of Electronics Engineering at the University of Oxford. By this time his output in research was of the nature of a staggering 200 publications and many patents. He was elected a Fellow of the Royal Society in 1984, and in 1986 he was awarded the Holweck Gold Medal and prize from the Institute of Physics and the French Physical Society.

In 1990 he joined the University of Sheffield as its Vice Chancellor and in his words he chose Sheffield "on account of its academic potential and the persuasive powers of its then Chancellor Lord Dainton”. He was at once a striking success at Sheffield where he was able to give the University a quality leadership and attract the people of the highest level to its ranks. He promoted interdisciplinary research, and enterprise in teaching. His own example of integrity and fairness engendered trust and confidence and the University gained much from his leadership and vision. Within the UK itself and internationally his influence was enormous. He was the driving force in the Dearing Inquiry into Higher Education, and many of its proposals which were later to become UK government policy. And he became an authority on Research Assessment, an exercise through which funding for research in the UK was rationalized in the universities and enhanced.

It was in this capacity that he visited Sri Lanka again, in 2000 at the invitation of the National Science and Technology Commission (NASTEC), and the Minister of Science and Technology, at the time Mr. Batty Weerakoon. He conducted a workshop together with Sri Lankan Scientists on the Methodology of Research Assessment. 
Once again he came to Sri Lanka a year later this time to assist us in the preparations for the Biennial Conference on Science and Technology (BICOST) where the theme was Science in Development.

Sir Gareth served as both President of the UK Science Council, and Chairman of the UK Engineering and Technology Board. He was also Chairman ofthe Defense Scientific Advisory Council, the Prime Minister's Advisory Council on Science and Technology, and Chairman of the
Higher Education Funding Councils Research Committee. At the time of his untimely death, Sir Gareth was the President of Wolfson College, Oxford, a position that he took on in January 2001.

Sir Gareth endeared himself to all scientists he worked with in Sri Lanka by his knowledge, skill and vision and by his disarmingly friendly manner. On behalf of all of them we send our condolences to Lady Carolyn, and the other members of his family.

\section{R.O.B.Wijesekera}

No. 16, Kirimandala Mawatha, Rajagiriya 